\title{
DEMOGRAPHIC PLASTICITY IN RELATION TO GROWTH AND RESOURCE ALLOCATION PATTERN IN ANTHEMIS COTULA -AN ALIEN INVASIVE SPECIES IN KASHMIR HIMALAYA, INDIA
}

\author{
R. R. ALLAIE - Z. RESHI*-B.A. WAFAI \\ *e-mail:zreshi@yahoo.com \\ ${ }^{1}$ Department of Botany, University of Kashmir, Srinagar-190 006, Jand, India \\ *Corresponding author \\ (Received $21^{\text {th }}$ March 2005; accepted $4^{\text {th }}$ August 2005)
}

\begin{abstract}
The demographic study of Anthemis cotula L. revealed a protracted seedling recruitment pattern with peaks in autumn (pre-winter) and spring (post-winter). The major recruitment pulse in autumn contributes to the fecundity component of the life history while the minor recruitment pulse in spring aids in survival of the species. The total drymass accumulation shows striking variations between the pre-winter and post-winter populations. Compared to post-winter population, the pre-winter plants show higher drymass accumulation due to higher relative growth rate (RGR) and consequently higher number of seeds per plant. Allocation of dry matter to leaves was also higher. The present studies indicate that A. cotula tends to allocate a greater proportion of total biomass to above ground than to below ground parts which is characteristic of species invading disturbed habitats The extent of resource allocation to reproduction exhibited by the species is characteristic of the habitats that are less mature and are highly disturbed.
\end{abstract}

Keywords: Anthemis cotula, demographic trade-off, dry matter allocation

\section{Introduction}

Invasion by exotic plant species is occurring at an unprecedented rate as a result of human activities that have increased the number of introductions and the rate of spread of many species $[42,16]$. These invasions have serious biological $[48,62]$, economic [50], and social [7] impacts which has led to a surge of interest in identifying morphological, growth and reproductive traits associated with invasiveness $[60,56,52$, 64]. Studies have revealed that exotic invasives often exhibit morphological, physiological and demographic plasticity $[17,26]$ which allows them to take advantage of a variety of habitats [8, 46]. Plasticity of a species has been suggested as one character for predicting invasiveness [57]. Also, plastic resource allocation of plants in response to varying growing conditions has been reported [30, 53, 54, 22].

Demographic plasticity in relation to growth, resource allocation and reproduction of invasive plant species has been little studied although demographic studies of plants have attempted to describe population dynamics of species in particular habitats and to obtain insights into microevolutionary processes that affect the life-history attributes $[14,63]$. In particular, it has been demonstrated that variability in establishment could cause differences in fitness among annual plants [9, 5, 68, 49] and, therefore, may promote life-history trade-offs among fitness components [37]. In view of the ecological significance of plasticity, present studies were carried on A. cotula to investigate the effect of demographic trade-off on growth, resource allocation and fitness of the individuals of two population cohorts and to gain insight into the strategies employed by the species to invade virgin areas in the Kashmir valley. 


\section{Materials and methods}

Anthemis cotula L. of family Asteraceae is an annual herb. Although native to the Mediterranean region it has been widely introduced as a weed of cultivation in temperate areas. Its European distribution extends northwards to southern Norway, central Sweden and southern Finland. In south its range extends to the Atlas Mountains and Canary Islands, and includes Egypt and western Asia. The species has also got introduced into USA, Canada, Argentina, Australia and New Zealand. In Kashmir valley, it is a non-native invasive species, forming almost mono-specific stands in ruderal habitats.

The present studies were conducted in the Mirza Bagh campus of the University of Kashmir, lying within the geographical co-ordinates of $34^{\circ} 5^{\prime}$ to $34^{\circ} 6^{\prime} \mathrm{N}$ latitude and $74^{\circ} 8^{\prime}$ to $74^{\circ} 9^{\prime} \mathrm{E}$ longitude at an altitude of 1586 meters above mean sea level. An area of 7 acres, previously occupied by a grassland, now supports vegetation dominated by A. cotula. For demographic study, five permanent quadrats of $50 \mathrm{~cm}^{2}$ were set up. The quadrats were surveyed after an interval of 15 days during the study period from the stage of seedling recruitment to maturation i.e. from September 2001 to June 2002, except during last half of January when the entire study area was snow covered. The seedlings, after attaining distinctive appearance, were marked using colour paint following Khushwaha et al., (1981) [39]. The marked seedlings were again counted on the subsequent census to record mortality and survival of the individuals. The seedlings without colour marking on each sampling date constituted the new recruits which after counting were marked with the colour paint in the permanent quadrats to distinguish between previous and new recruits on successive sampling dates. The cumulative gains and losses in the population were obtained on the basis of data on new recruits and mortality at different census dates [29].

\section{Growth analysis}

Growth analysis was carried on pre- and post-winter populations. Pre-winter population was raised before the onset of winter during September-October and postwinter population after winter with the onset of spring during February-March. The populations were raised from one year old achenes sown in experimental pots of $30 \mathrm{~cm}$ diameter, filled with garden soil and sand in the ratio of 3:1. The pots were irrigated weekly in the early morning and in the late afternoon. The seedlings after emergence were thinned and 5 seedlings of almost equal size were maintained in each plot. 100 pots of each population were maintained for further studies.

Sampling was done after every fortnight and on each sampling date, 5 plants were randomly harvested. Soil was washed off from the roots and the plants were divided into three samples. Number of tillers, inflorescences, and achenes (when present) was counted and in each sample the stem height was also measured. The samples were separated into leaves, stem, root and at later stages into reproductive parts and standing dead as well. The plant material was oven dried at $800^{\circ} \mathrm{C}$ for 24 hours to constant weight and the dry mass of each component was determined using an electronic balance. The growth parameters computed included:

\section{Relative growth rate}

Relative growth rate (RGR), also called Efficiency Index by Blackman (1919) [12], represents the efficiency of the plant as a producer of new material. It is analogous to 
the rate of interest earned. RGR provides a convenient interaction of the combined performance of various parts of the plant. Since it refers to growth in relation to mass it provides a more informative comparison of relative performance of plant. The value of RGR over a period of time $T_{1}$ to $T_{2}$ was obtained by the following formula:

$$
R G R=\frac{\log _{e} W_{2}-\log _{e} W_{1}}{T_{2}-T_{1}}
$$

where, $\mathrm{W}_{2}$ and $\mathrm{W}_{1}$ are the total plant dry weights at times $\mathrm{T}_{2}$ and $\mathrm{T}_{1}$, respectively. RGR obtained by above formula was expressed in $\mathrm{gg}^{-1} \mathrm{day}^{-1}$.

\section{Root:shoot ratio}

Root:shoot ratio (RSR) is the ratio between total dry weight of roots shoot or total above ground dry weight of the plant. The advantage of RSR is that this quantity is by its very structure more responsive to the change than root or shoot weight ratios, particularly when shoot weight $(\mathrm{SW})$ is greater than root weight (RW) or vice versa. This quantity is very sensitive to environmental influences [35].

$$
\mathrm{RSR}=\mathrm{RW} / \mathrm{SW}
$$

\section{Root weight ratio (RWR)}

Root weight ratio is the ratio between total dry weight of the roots per plant (TRW) and total dry weight per plant (TDW).

$$
\mathrm{RWR}=\mathrm{TRW} / \mathrm{TDW}
$$

\section{Shoot weight ratio}

Shoot weight ratio (SWR) is the ratio between total dry weight of the shoot (TSW) and the total dry weight per plant (TDW)

$$
\mathrm{SWR}=\mathrm{TSW} / \mathrm{TDW}
$$

\section{Leaf weight ratio}

Leaf weight ratio (LWR) is an index of leafiness of the plant on dry weight basis. It is a measure of the productive investment of the plant because it deals with the relative expenditure on potentially photosynthesizing organs. It is the ratio between total dry weight of the leaves (TLW) and the total dry weight per plant (TDW).

$$
\mathrm{LWR}=\mathrm{TLW} / \mathrm{TDW}
$$

\section{Results}

Data on population size, recruitment pattern and mortality (Fig.1) reveal that maximum population size was recoded before winter during September, followed by a decline till March. The number of individuals again increased in April with the onset of favourable conditions but declined subsequently. Population size closely followed the recruitment pattern which occurred in two pulses. The major peak in recruitment was 
recorded in September during autumn season and minor peak in April (after the end of winter).

Mortality showed an irregular pattern (Fig. 1) but highest number of deaths was recorded only in autumn immediately after mass recruitment of the seedlings. Thereafter, mortality declined but remained more or less uniform till December. Mortality was again recorded in April after the second wave of recruitment, after which the population size remained more or less stable.

Figure 1. Size, recruitment and mortality pattern in natural populations of Anthemis cotula

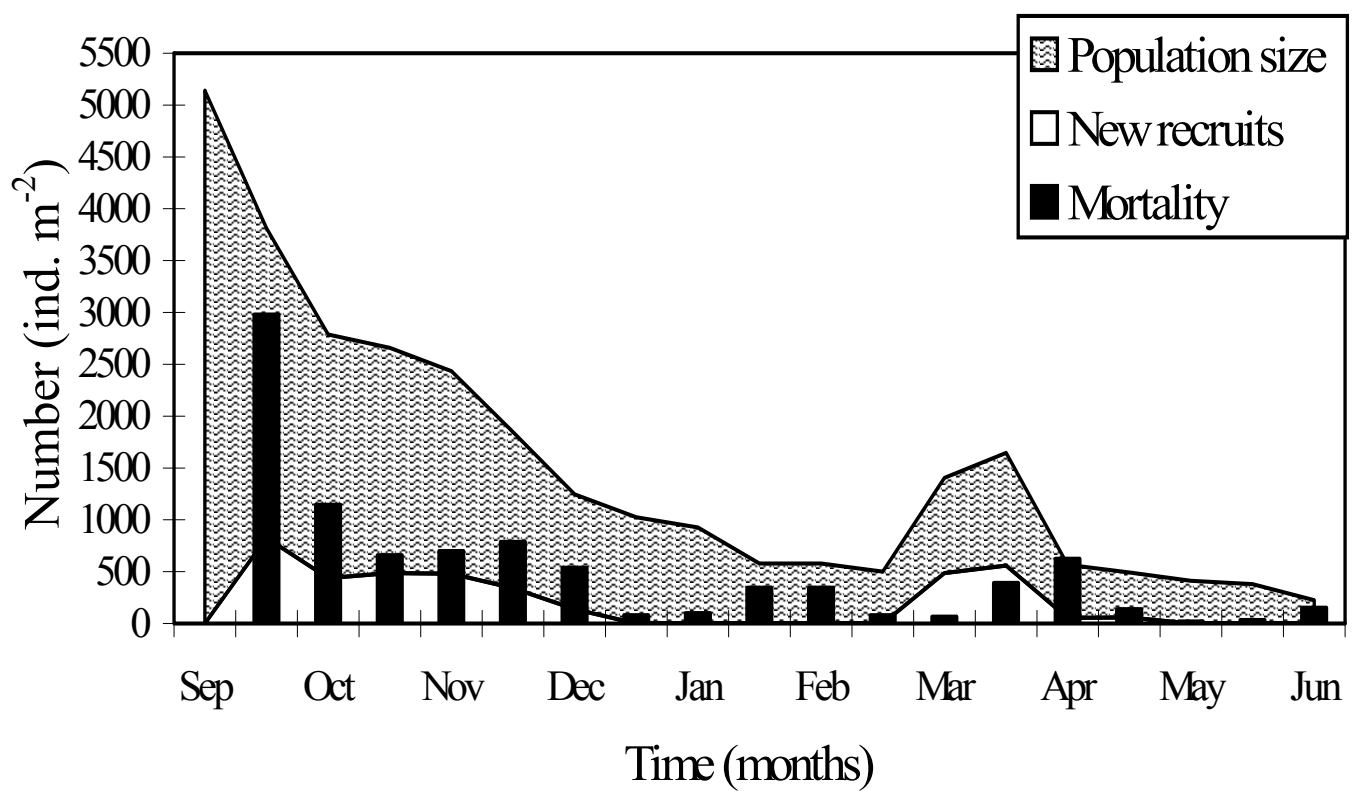

\section{Growth pattern}

The pre- and post-winter populations differed considerably in different growth attributes (Tables 1 and 2 ). The RGR in the population sown prior to winter increased from an initial value of 0.008 g.g-1 day-1 to a peak value of 0.0354 g.g-1 day-1 after 173 days of emergence and thereafter it registered a decline(Table 1). The post-winter population showed higher RGR (Table 2), immediately after emergence, and such a trend continued up to 72 days after emergence when highest value of 0.049 g.g-1 day-1 was obtained. Subsequent to this initial burst in growth, a sharp decline was registered except at maturity when the population showed some increase in growth rate.

RSR in both pre- and post-winter populations (Tables 1 and 2) was higher during vegetative stages compared to later stages of the life history. In the population sown prior to winter, the highest value (0.500) of RSR was recorded after 158 days of emergence, whereas in post winter sown population, the highest value of 0.393 was obtained just 27 days after emergence. Lowest values of 0.087 and 0.062 in pre- and post-winter sown populations, respectively, were observed at the senescence phase of the two populations. RWR (Tables 1 and 2) also recorded highest values during the initial stages of life history, both in pre- and post-winter populations. In the former, highest value of 0.333 was obtained 158 days after emergence while the lowest value of 0.080 was observed at the senescence phase. Likewise in post-winter population the 
highest value of 0.282 was recorded only 27 days after emergence and the lowest value of 0.058 was obtained at senescence. Contrary to RSR and RWR, the SWR in both the populations (Tables 1 and 2) increased with age. In pre- and post-winter population the highest values obtained at the senescence phase were 0.919 ad 0.941 , respectively.

Figure 2. Comparison of drymatter allocation (\%) to different plant parts in pre-and post-winter populations of

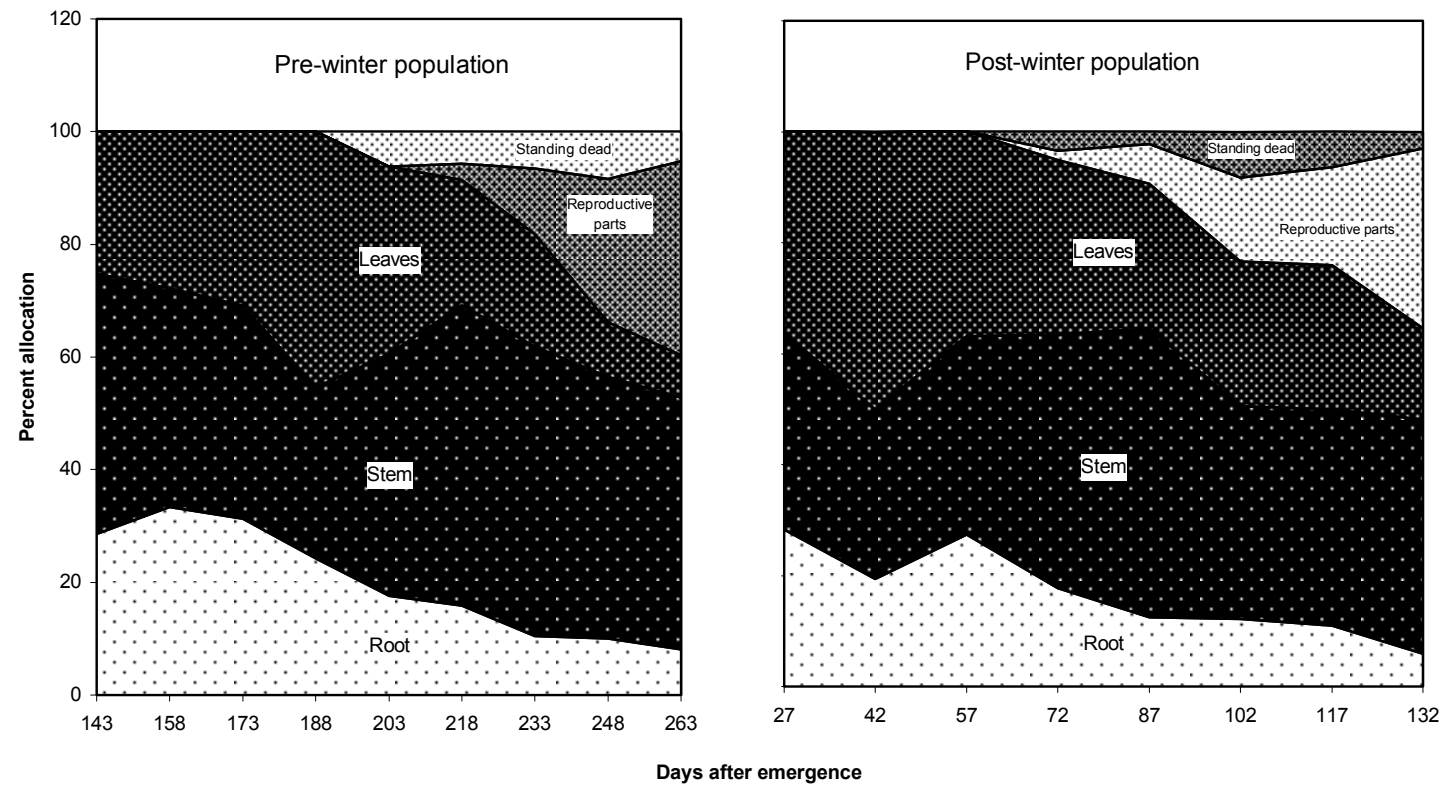

LWR in pre-winter sown population (Table 1) registered an increase up to 188 days after emergence when the highest value of 0.454 was recorded followed by consistent decline till the end of the life cycle. The pattern was more or less similar in post-winter sown population where the highest value of 0.500 for the ratio was observed only 42 days after emergence. Beyond this stage, the LWR exhibited decline.

Table 1. Growth characteristics of pre-winter population of A. cotula.

\begin{tabular}{|c|c|c|c|c|c|c|c|c|}
\hline \multirow{2}{*}{ Parameter } & \multicolumn{7}{|c|}{ Days after emergence } \\
\cline { 2 - 9 } & $\mathbf{1 4 3}$ & $\mathbf{1 5 8}$ & $\mathbf{1 7 3}$ & $\mathbf{1 8 8}$ & $\mathbf{2 0 3}$ & $\mathbf{2 1 8}$ & $\mathbf{2 3 3}$ & $\mathbf{2 4 8}$ \\
\hline $\begin{array}{c}\text { Root-shoot ratio } \\
\text { (RSR) }\end{array}$ & 0.421 & 0.500 & 0.450 & 0.319 & 0.213 & 0.187 & 0.117 & 0.111 \\
\hline $\begin{array}{c}\text { Root-weight } \\
\text { ratio(RWR) }\end{array}$ & 0.285 & 0.333 & 0.309 & 0.242 & 0.175 & 0.158 & 0.104 & 0.100 \\
\hline $\begin{array}{c}\text { Shoot weight ratio } \\
\text { (SWR) }\end{array}$ & 0.714 & 0.666 & 0.689 & 0.757 & 0.824 & 0.841 & 0.895 & 0.899 \\
\hline $\begin{array}{c}\text { Leaf weight ratio } \\
\text { (LWR) }\end{array}$ & 0.252 & 0.277 & 0.309 & 0.454 & 0.332 & 0.222 & 0.200 & 0.096 \\
\hline $\begin{array}{c}\text { Relative growth } \\
\text { rate (RGR)gg-1 } \\
\text { day }^{-1}\end{array}$ & - & 0.008 & 0.043 & 0.030 & 0.035 & 0.013 & 0.017 & 0.023 \\
\hline
\end{tabular}


Dry matter accumulation in both the experimental populations showed an increase with age. Comparative analysis of the data reveals higher dry mass in individuals of prewinter sown population. Allocation of dry matter to different components (Tables 3 and 4) reveals higher contribution to stem followed by reproductive parts, in both the populations, although the allocation to different plant parts was consistently higher in the population raised before winter in comparison to population grown after the winter. The allocation pattern of dry matter worked out on percentage basis in both the populations (Fig. 2) also points towards increase in allocation to reproductive parts with age at the expense of allocation to stem, root and leaves.

Table 2. Growth characteristics of post-winter population of A. cotula

\begin{tabular}{|c|c|c|c|c|c|c|c|c|}
\hline \multirow{2}{*}{ Parameter } & \multicolumn{7}{|c|}{ Days after emergence } \\
\cline { 2 - 9 } & $\mathbf{2 7}$ & $\mathbf{4 2}$ & $\mathbf{5 7}$ & $\mathbf{7 2}$ & $\mathbf{8 7}$ & $\mathbf{1 0 2}$ & $\mathbf{1 1 7}$ & $\mathbf{1 3 2}$ \\
\hline $\begin{array}{c}\text { Root-shoot ratio } \\
\text { (RSR) }\end{array}$ & 0.393 & 0.241 & 0.377 & 0.216 & 0.142 & 0.138 & 0.122 & 0.062 \\
\hline $\begin{array}{c}\text { Root-weight } \\
\text { ratio(RWR) }\end{array}$ & 0.282 & 0.194 & 0.274 & 0.177 & 0.124 & 0.121 & 0.109 & 0.058 \\
\hline $\begin{array}{c}\text { Shoot weight ratio } \\
\text { (SWR) }\end{array}$ & 0.717 & 0.805 & 0.725 & 0.822 & 0.874 & 0.878 & 0.890 & 0.941 \\
\hline $\begin{array}{c}\text { Leaf weight ratio } \\
\text { (LWR) }\end{array}$ & 0.363 & 0.500 & 0.369 & 0.314 & 0.260 & 0.260 & 0.259 & 0.165 \\
\hline $\begin{array}{c}\text { Relative growth } \\
\text { rate (RGR)gg } \\
\text { day }^{-1}\end{array}$ & - & 0.031 & 0.038 & 0.049 & 0.017 & 0.009 & 0.009 & 0.027 \\
\hline
\end{tabular}

Comparative analysis of vegetative and reproductive attributes of the two populations at maturity (Table 5) reveals higher values for stem height and number of tillers, branches, inflorescences and achenes/plant in pre-winter compared to post-winter population. The number of branches/tiller, however, was higher in post-winter population while the 1000 achene weight was almost same in both the populations.

Table 3. Dry matter (g/plant) allocation pattern in pre-winter population of A. cotula. (Mean and \pm standard deviation based on 3 replicates of 5 plants each)

\begin{tabular}{|c|c|c|c|c|c|c|c|c|c|}
\hline \multirow[t]{2}{*}{ Component } & \multicolumn{9}{|c|}{ Days after emergence } \\
\hline & 143 & 158 & 173 & 188 & 203 & 218 & 233 & 248 & 263 \\
\hline Stem & $\begin{array}{c}0.012 \\
\pm 0.007\end{array}$ & $\begin{array}{c}0.014 \\
\pm 0.001\end{array}$ & $\begin{array}{c}0.061 \\
\pm 0.002\end{array}$ & $\begin{array}{c}0.139 \\
\pm 0.021\end{array}$ & $\begin{array}{c}0.669 \\
\pm 0.190\end{array}$ & $\begin{array}{c}1.336 \\
\pm 0.114\end{array}$ & $\begin{array}{c}2.356 \\
\pm 1.035\end{array}$ & $\begin{array}{c}4.788 \\
\pm 3.245\end{array}$ & $\begin{array}{c}7.705 \pm \\
5.917\end{array}$ \\
\hline Root & $\begin{array}{c}0.008 \\
\pm 0.003 \\
\end{array}$ & $\begin{array}{c}0.012 \pm \\
0.004\end{array}$ & $\begin{array}{c}0.050 \pm \\
0.018\end{array}$ & $\begin{array}{c}0.111 \pm \\
0.041\end{array}$ & $\begin{array}{c}0.274 \pm \\
0.033\end{array}$ & $\begin{array}{c}0.396 \pm \\
0.036\end{array}$ & $\begin{array}{c}0.481 \pm \\
0.094\end{array}$ & $\begin{array}{c}1.038 \pm \\
0.528\end{array}$ & $\begin{array}{c}1.389 \pm \\
0.244\end{array}$ \\
\hline Leaves & $\begin{array}{c}0.007 \\
\pm 0.001\end{array}$ & $\begin{array}{c}0.010 \pm \\
0.001\end{array}$ & $\begin{array}{c}0.050 \pm \\
0.007\end{array}$ & $\begin{array}{c}0.208 \pm \\
0.074\end{array}$ & $\begin{array}{c}0.517 \pm \\
0.131\end{array}$ & $\begin{array}{c}0.558 \pm 0 . \\
078\end{array}$ & $\begin{array}{c}0.919 \pm \\
0.068\end{array}$ & $\begin{array}{c}0.998 \pm \\
0.367\end{array}$ & $\begin{array}{c}1.293 \pm \\
1.356\end{array}$ \\
\hline $\begin{array}{l}\text { Reproductive } \\
\text { parts }\end{array}$ & - & - & - & - & - & $\begin{array}{c}0.073 \\
\pm 0.054\end{array}$ & $\begin{array}{c}0.524 \\
\pm 0.358\end{array}$ & $\begin{array}{c}2.630 \\
\pm 1.795\end{array}$ & $\begin{array}{c}5.937 \\
\pm 4.524\end{array}$ \\
\hline Standing dead & - & - & - & - & $\begin{array}{c}0.097 \\
\pm 0.048\end{array}$ & $\begin{array}{c}0.142 \\
\pm 0.074\end{array}$ & $\begin{array}{c}0.303 \\
\pm 0.109\end{array}$ & $\begin{array}{c}0.866 \\
\pm 0.657\end{array}$ & $\begin{array}{r}0.900 \\
\pm 0301\end{array}$ \\
\hline
\end{tabular}


Table 4. Dry matter (g/plant) allocation pattern in post-winter population of A. cotula . (Mean and \pm standard deviation based on 3 replicates of 5 plants each

\begin{tabular}{|c|c|c|c|c|c|c|c|c|c|}
\hline \multirow[t]{2}{*}{ Component } & \multicolumn{9}{|c|}{ Days after emergence } \\
\hline & 27 & 42 & 57 & 72 & 87 & 102 & 117 & 132 & 27 \\
\hline Stem & $\begin{array}{c}0.004 \\
\pm 0.0002\end{array}$ & $\begin{array}{c}0.011 \\
\pm 0.001\end{array}$ & $\begin{array}{c}0.048 \\
\pm 0.001\end{array}$ & $\begin{array}{c}0.346 \\
\pm 0.021 \\
\end{array}$ & $\begin{array}{c}0.730 \\
\pm 0.100\end{array}$ & $\begin{array}{c}0.755 \\
\pm 0.272\end{array}$ & $\begin{array}{c}1.075 \\
\pm 0.026\end{array}$ & $\begin{array}{c}3.106 \\
\pm 1.517\end{array}$ & $\begin{array}{c}0.004 \\
\pm 0.0002\end{array}$ \\
\hline Root & $\begin{array}{c}0.003 \\
\pm 0.001 \\
\end{array}$ & $\begin{array}{c}0.007 \\
\pm 0.003 \\
\end{array}$ & $\begin{array}{c}0.037 \\
\pm 0.002 \\
\end{array}$ & $\begin{array}{c}0.134 \\
\pm 0.008 \\
\end{array}$ & $\begin{array}{c}0.175 \\
\pm 0.039 \\
\end{array}$ & $\begin{array}{c}0.240 \\
\pm 0.142 \\
\end{array}$ & $\begin{array}{c}0.301 \\
\pm 0.019 \\
\end{array}$ & $\begin{array}{c}0.434 \\
\pm 0.049 \\
\end{array}$ & $\begin{array}{c}0.003 \\
\pm 0.001 \\
\end{array}$ \\
\hline Leaves & $\begin{array}{c}0.005 \\
\pm 0.006 \\
\end{array}$ & $\begin{array}{c}0.018 \\
\pm 0.002 \\
\end{array}$ & $\begin{array}{c}0.050 \\
\pm 0.005 \\
\end{array}$ & $\begin{array}{c}0.238 \\
\pm 0.013 \\
\end{array}$ & $\begin{array}{c}0.365 \\
\pm 0.099 \\
\end{array}$ & $\begin{array}{c}0.514 \\
\pm 0.052 \\
\end{array}$ & $\begin{array}{c}0.716 \\
\pm 0.117 \\
\end{array}$ & $\begin{array}{c}1.216 \\
\pm 0.107 \\
\end{array}$ & $\begin{array}{c}0.005 \\
\pm 0.006 \\
\end{array}$ \\
\hline $\begin{array}{l}\text { Reproductive } \\
\text { parts }\end{array}$ & - & - & - & $\begin{array}{c}0.012 \\
\pm 0.004\end{array}$ & $\begin{array}{c}0.099 \\
\pm 0.0004\end{array}$ & $\begin{array}{c}0.300 \\
\pm 0.057\end{array}$ & $\begin{array}{c}0.487 \\
\pm 0.095\end{array}$ & $\begin{array}{c}2.389 \\
\pm 0.053\end{array}$ & - \\
\hline Standing dead & - & - & - & $\begin{array}{c}0.026 \\
\pm 0.016 \\
\end{array}$ & $\begin{array}{c}0.032 \\
\pm 0.017 \\
\end{array}$ & $\begin{array}{c}0.162 \\
\pm 0.011 \\
\end{array}$ & $\begin{array}{c}0.177 \\
\pm 0.004 \\
\end{array}$ & $\begin{array}{c}0.219 \\
\pm 0.082 \\
\end{array}$ & - \\
\hline
\end{tabular}

\section{Discussion}

The present studies reveal that in the Kashmir Himalaya recruitment of A. cotula occurs in two pulses. Major pulse in recruitment occurs before winter in autumn and a minor pulse after winter in spring. Similar pattern of recruitment in this species has been reported by Kay (1970) [38]. The species experiences considerable mortality during winter which in other winter annuals has been attributed to frost heaving of the soil [55, 44]. Apart from frost heaving, the mortality in A. cotula may be due to strong intraspecific competition between the seedlings since the seedling density is very high during the initial stages (Fig. 1). However, Mack (1976) [43] and Watkinson and Harper (1978) [70], did not observe significant mortality during seedling stage in non-rosette forming winter annuals. Results of the present study clearly demonstrate temporal variability in germination time and thereby recruitment. Similar results were obtained by Gonzalez-Astorga and Nunez-Farfan (2000) [26] in Tagetes micrantha. Furthermore, an ecological trade-off between survival and fecundity was detected in relation to seedling emergence time, as striking differences in survivorship and fecundity among pre-and post-winter populations were observed [6]. This phenotypic variation in the life history trait of emergence time is ecologically and evolutionarily important due to its effect in determining species fitness $[9,5,45,69,40,49,68]$. The variation in emergence time has been reported to be the result of both genetic variation and phenotypic plasticity [61]. In A. cotula, environmental control of emergence seems evident but the existence of genetic predisposition needs to be determined. In Tagetes micrantha variation in emergence time has been reported to be controlled both by environmental [21] as well as genetic factors[26]. This life-history trade-off had a significant effect on resource allocation pattern in the population cohorts since the total dry matter accumulation exhibited striking variations between the pre-winter and postwinter populations. The pre-winter plants displayed higher drymass accumulation (Table 3) due to higher RGR and consequently higher number of seeds per plant (Table 5). These differences could be attributed either to differences in length of the growing period or to environmental conditions. Differences in biomass production between plant species has been attributed to a wide variety of factors [51]. The most extensive study 
on interspecfic variation in RGR is that of Grime and Hunt (1975) [28], who compared 130 herbaceous annuals, perennials and tree seedlings and reported RGR ranging from 0.031 to $0.386 \mathrm{~g}$ g-1 day-1. Grime and Hunt (1975) [28] and Grime (1979) [27] distinguished 3 different groups of species; ruderals, competitors and stress-tolerants. A. cotula belongs to the ruderal category and exhibits high RGR. The ecological advantage of high RGR seems clear as fast growth results in the rapid occupation of a large space which is advantageous in competitive situations [28]. A high RGR may also facilitate rapid completion of the life cycle, so essential for ruderals [51]. How fast growing species achieve high RGR has been frequently addressed. In the studies carried on 24 species by Poorter and Remkes (1990) [51], RGR did not show a clear correlation with NAR implying that the carbon economy, the balance of photosynthesis and respiration expressed per unit leaf area, is not of overriding importance in explaining variation in RGR. Allocation of dry matter to leaves (LWR) is higher in A. cotula as has been reported for other fast growing species too [51], but without any significant correlation with RGR. The present studies indicate that A. cotula tends to allocate a greater proportion of total biomass to above ground parts than to below ground ones which is characteristic of species invading disturbed habitats $[3,24,1]$. The distribution of biomass among the various plant organs depends to a large degree on the nature of the limiting resources. Abrahamson and Gadgil (1973) [3] argued that if light is a limiting factor, then the plant may respond either by allocating more biomass to stem which results in taller plants, the strategy helpful in avoiding shade or to leaves which intercept more of the available light. These patterns of resource allocation have been observed in golden rods [3] sunflowers [24] and little blue stem [59]. Both these strategies seem to be adopted by A. cotula to maximize its growth rate leading to high reproductive output which aids in its spread. Such optimization of resources by plants in response to environmental conditions has also been reported by Thornley (1972) [66], Bloomn et al., (1985) [13], Robinson (1986) [58], Hirose (1987) [34], Johnson and Thornley (1987) [36], Szaniawski (1987) [65], Levin et al., (1989) [41], Hilbert (1990) [33] and Dewar (1993) [20] in different taxa. Decreased allocation to roots has been reported for Eucalyptus seedlings [18, 19], tropical perennial grasses [31], temperate annual grasses [67] and old field annuals [25] invariably from nutrient enriched environments.

Table 5. Vegetative and reproductive characteristics at maturity in pre- and post-winter populations of A. cotula. (Mean and \pm standard deviation based on 3 replicates of 5 plants each).

\begin{tabular}{|l|l|c|c|}
\hline $\begin{array}{l}\text { Site } \\
\text { No. }\end{array}$ & \multicolumn{1}{|c|}{ Parameter } & $\begin{array}{c}\text { Pre-winter } \\
\text { population }\end{array}$ & $\begin{array}{c}\text { Post-winter } \\
\text { population }\end{array}$ \\
\hline 1 & Stem height $(\mathrm{cm})$ & $77.330 \pm 13.620$ & $69.000 \pm 6.244$ \\
\hline 2 & Number of tillers/plant & $2.000 \pm 1.000$ & $1.000 \pm 0$ \\
\hline 3 & Number of branches/tiller & $10.500 \pm 3.968$ & $13.660 \pm 0.570$ \\
\hline 4 & Number of branches/plant & $19.000 \pm 6.928$ & $13.660 \pm 0.570$ \\
\hline 5 & Number of inflorescences/plant & $88.000 \pm 66.340$ & $63.330 \pm 45.930$ \\
\hline 6 & Number of achenes/plant & $12,419 \pm 37.214$ & $7203.787 \pm 21.540$ \\
\hline 7 & 1000 achene weight $(\mathrm{g})$ & 0.393 & 0.385 \\
\hline
\end{tabular}


The underlying physiological mechanisms that determine the observed allocation patterns are still largely unknown [71] and many of these mechanisms are hormonally mediated [15] which have been scarcely studied. The variations in the allocation of resources to different plant organs in pre- and post-winter populations of A. cotula (Tables 3,4 and Fig. 2) could be due to different growth forms of the plants. For example, basal rosette habitats in pre-winter plants can alter the resource allocation pattern and such observations draw support from the studies carried out by Abrahamson (1979) [2] on 52 populations of 50 wild species.

Allocation of resources to reproductive structures has been particularly studied in detail [29, 10, 11] because reproductive allocation and its controls are clearly key questions in the long term population and evolutionary perspective,. In view of this, allocation to reproduction was studied in A. cotula, which revealed an allocation of around 30 percent resources to seeds in both pre- and post-winter populations inspite of significant differences in total drymass/plant in two populations. The allocation of resources to reproduction recorded during the present study is characteristic of the species that inhabit less mature and highly disturbed habitats $[3,24,1,2]$. Such a characteristic allocation pattern has been attributed, by some, to genetic factors [23] while others have shown it to be environmentally cued plastic response of the plants $[32,4]$.

The present data (Table 5) clearly suggest that individuals in the pre-winter population have a significantly high fecundity (12,419 achenes/plant) while individuals in post-winter population produce only 7,204 achenes/plant. However, individuals in the latter population experience less mortality compared to the former population. Thus, variation in plant emergence time in A. cotula produces a life history trade-off, with early emergence favouring the fecundity component of fitness and late emergence favouring the survival component. These observations are supported by the studies carried out by Mosseau et al., (2000) [47].

In conclusion it can be stated that the invasion of local ruderal habitats in Kashmir Himalaya by A. cotula is due to the fine tuning of its life history strategy to the prevailing environmental conditions. Protracted recruitment pattern aided by habitat disturbance and favourable moisture, temperature, light and nutrient regimes, and high population size even after seedling mortality are the key attributes contributing to the establishment and spread of this species.

Acknowledgements. The authors are grateful to Head, Department of Botany, University of Kashmir, Srinagar, for providing laboratory facilities.

\section{REFERENCES}

[1] Abrahamason WG (1975): Reproductive strategies in dewberries. - Ecology, 56: 721726.

[2] Abrahamason WG (1979): Patterns of resource allocation in wild flower populations of fields and woods. - Amer. J. Bot. 66: 71-79.

[3] Abrahamason WG and Gadgil MD (1973): Growth form and reproductive effort in goldenrods (Solidago, Compositae). - Am. Na. 107: 651-661.

[4] Abrahamason WG and Hershey B (1977): Resource allocation and growth of Impatiens capensis (Balsaminaceae) in two habitats. - Bull. Torry Bot.Club.104: 160-164. 
[5] Abul-Fatih H. and Bazzaz F (1979): The biology of Ambrosia trifida L. II. Germination, emergence, growth and survival. - New Phytologist, 83: 817-827.

[6] Allaie RR. (2003): Ecological and reproductive strategies of Anthemis cotula L. (Asteraceae)....An alien invasive species in Kashmir. - M.Phil Dissertation, University of Kashmir, Srinagar.

[7] Asher J and Spurrier C (1998): The spread of invasive weeds in western wildlands. http://www.blm.gov/BIOSUMMI.wpd.htm.

[8] Baker HG (1974): The evolution of weeds. - Annual Review of Ecology and Systematics, 5: 1-24.

[9] Baskin JM and Baskin CC (1972): Influence of germination date on survival and seed production in a natural population of Leavenworthia stylosa. - American Midland Naturalist, 88: 318-323.

[10] Bazzaz FA and Reckie EG (1985): The meaning and measurement of reproductive effort in plants. In: White J (eds.). Studies in plant demography: A Festschrift for John L. Harper . - Academic Press London pp 259-275.

[11] Bazzaz FA Chiariello NR Coley PD and Pitelka LF (1987): Allocating resources to reproduction and defense. - Bio Science, 37: 58-67.

[12] Blackman VH (1919): The compound interest law and plant growth. - Annals of Botany, 33:353-360.

[13] Bloom A J Chapin FS and Mooney HA (1985): Resource limitation in plants-an economic analogy. - Annual Review of Ecology and Systematics, 16: 363-392.

[14] Bradshaw A (1984): The importance of evolutionary ideas in ecology and vice versa. In: Shorrocks, BS (ed.) Evolutionary Ecology. - Blackwell Scientific Publishers, Oxford, UK.

[15] Chapin FS (1991): Effects of multiple environmental stresses on nutrient availability and use. In: Mooney HA Winner WE and Pell EJ (eds.) Responses of plants to multiple stresses. - Academic Press, San Diego, California, USA. pp 67-88.

[16] Chapin FS III Zavaleta ES Eviner VT Naylor RL Vitousek PM Reynolds HL Hooper DU et al. (2000): Consequences of changing biodiversity. - Nature, 405:234-242.

[17] Claridge K and Franklin SB (2002): Compensation and plasticity in an invasive plant species. - Biological Invasions, 4: 339-347.

[18] Cromer RN and Jarvis PG (1989): Allocation of dry matter in Eucalyptus grandis seedlings in response to nitrogen supply. - Annales des Sciences Forestieres, 46: 680683.

[19] Cromer RN Wheeler AM and Barr NJ (1984): Mineral nutrition and growth of Eucalyptus seedlings. - New Zealand Journal of Forestry Science, 14: 229-239.

[20] Dewar RC (1993): A root-shoot-partitioning model based on carbon-nitrogen-water interactions and Munch phloem flow. - Functional Ecology, 7: 356-368.

[21] Dominguez CA. and Dirzo R (1995): Rainfall and flowering synchrony in a tropical shrub: variable selection on the flowering time of Erythroxylum havanense. Evolutionary Ecology, 9: 204-216.

[22] Dong M and de Kroon H (1994): Plasticity in morphology and biomass allocation in Cynodon dactylon, a grass species forming stolons and rhizomes. - Oikos, 70: 99-106.

[23] Gadgil MD and Solbrig OT (1972): The concept of $\mathrm{r}$ and k selection: Evidence from wildflowers and some theoretical considerations. - Am. Nat. 106: 14-31.

[24] Gaines MS Vogt KS and Caldwell J (1974): Reproductive strategies and growth patterns in sunflowers. - Am. Nat. 108: 889-894.

[25] Gedroc JJ McConnaughay KDM and Coleman JS (1996): Plasticity in root/shoot partitioning optimal, ontogenetic, or both? - Functional Ecology, 10: 44-50.

[26] González-Astorga $J$ and Núñez-Farfan J (2000): Variable demography in relation to germination time in the annual plant Tagetes micrantha Cav. (Asteraceae). - Plant Ecology, 151: 253-259. 
[27] Grime JP (1979): Plant Strategies and Vegetation processes. - John Wiley and Sons, Chichester.

[28] Grime JP and Hunt R (1975): Relative growth rate : its range and adaptive significance in a local flora. - J. Ecol. 63:393-422.

[29] Harper JL (1977): Population Biology of Plants. - Academic Press, London.

[30] Harper JL and Ogden J (1970): The reproductive strategy of higher plants. I. The concept of strategy with special reference to Senecio vulgaris L. - J .Ecol. 58: 681-698.

[31] Hartvigsen G and McNaughton SJ (1995): Trade-off between height and relative growth rate in a dominant grass from the Serengeti ecosystem. - Oecologia, 102: 273-276

[32] Hickman JC (1975): Environmental unpredictability and plastic energy allocation strategies in the annual Polygonum cascadense. - J.Ecol. 63: 689-701.

[33] Hilbert DW (1990): Optimization of plant root:shoot ratios and internal nitrogen concentrations. - Annals of Botany, 66: 91-99.

[34] Hirose T (1987): A vegetative plant growth model: adaptive significance of phenotypic plasticity in matter partitioning. - Functional Ecology, 1: 195-202.

[35] Hunt R and Burnett JA (1973) The effect of light intensity and external potassium level on root/shoot ratio and rates of potassium uptake in perennial ryegrass (Lolium perenne L.). - Annuals of Botany, 37:519-537

[36] Johnson IR and Thornley JHM (1987): A model for root:shoot partitioning and optimal growth. - Annals of Botany, 60:133-142.

[37] Kalisz S (1986): Variable selection on the timing germination in Collinsia verna (Scrophulariaceae). - Evolution, 40: 479-491.

[38] Kay QON (1958): Biological flora of the British Isles: Anthemis cotula L. Journal of Ecology, 59: 623-636.

[39] Kushwaha SPS Ramakrishanan PS and Tripathi RS (1981): Population dynamics of Eupatorium odoratum in successional environments following slash and burn agriculture. - Journal of Ecology, 18: 529-535.

[40] Leon J (1985): Germination strategies. In: Greenwood P Harvey PH and Slatkin M (eds.) Evolution. Essays in honour of John Maynard Smith. - Cambridge University Press, Cambridge, UK.

[41] Levin SA Mooney HA and Field CB (1989): The dependence of plant root:shoot ratios on internal nitrogen concentration. - Annals of Botany, 64: 71-76.

[42] Lodge DM (1993): Biological invasions: Lessons from ecology. - Trends in Ecology and Evolution, 8: 133-136.

[43] Mack RN (1976) Survivorship of Cerastium atrovirens at Aberffraw, Anglessey. Journal of Ecology, 64: 309-314.

[44] Mack RN and Pyke DA (1983): The demography of Bromus tectorum: variation in time and space. - Journal of Ecology, 71: 69-93.

[45] Marks M. and Price S (1981): Influence of germination date on survival and fecundity in wild lettuce Lactuca serriola. - Oikos, 36: 326-330.

[46] Meekins JF and McCarthy BC (2001): Effect of environmental variation on the invasive success of a nonindigenous forest herb. - Ecological Applications, 11: 1336-1348

[47] Mosseau TA Sinervo B and Endler J (2000): Adaptive Genetic Variation in the Wild. Oxford University Press, London, New York.

[48] Noss RF LaRoe ET Scott JM (1995): Endangered ecosystems of the United States: a preliminary assessment of loss and degradation. - Nat Biol Serv Biol Rep. 128:58

[49] Philippi T (1993): Bet-hedging germination of desert annuals: variation among populations and maternal effects in Lepidium lasiocarpum. - American Naturalist, 142: 488-507.

[50] Pimental D Lach L Zuniga R and Morrision D (2000): Environmental and economic costs associated with non-indigenous species in the United States. - Boiscience, 50: 53-65. 
[51] Poorter H and Remkes C (1990): Leaf area ratio and net assimilation rate of 24 wild species differing in relative growth rate. - Oecologia, 83: 553-559.

[52] Pysek P (2001): Past and future of predictions in plant invasions: a field test by time. Divers Distrib. 7:145-151.

[53] Reekie EG and Bazzaz FA (1987a): Reproductive effort in plants. 2. Does carbon reflect the allocation of other resources? - American Naturalist, 129: 897-906.

[54] Reekie EG and Bazzaz FA (1987b): Reproductive effort in plants. 3. Effects of reproduction on vegetative activity. - American Naturalist, 129: 907-919.

[55] Regehr DL and Bazzaz FA (1979): The population dynamics of Erigeron canadensis, a successional winter annual. - Journal of Ecology, 66: 923-933.

[56] Reichard SH and Hamilton CW (1997): Predicting invasions of woody plants introduced into North America. - Conserv Biol. 11:193-203.

[57] Rejm' anek M and Richardson DM (1996): What attributes make some plant species more invasive? - Ecology, 77: 1655-1661.

[58] Robinson D (1986): Compensatory changes in the partitioning of dry matter in relation to nitrogen uptake and optimal variations in growth. - Annals of Botany, 58: 841-848.

[59] Roos FH and Quinn JA (1977): Phenology and reproductive allocation in Andropogon scoparius population in communities of different successional stages. - Amer.J.Bot. 64: 535-540.

[60] Roy J (1990): In search of the characteristics of plant invaders. In: di Castri F Hansen AJ Debussche $M$ (eds.) Biological invasions in Europe and the Mediterranean Basin. Kluwer Academic, Dordrecht, pp 335-352.

[61] Schlichting CD and Pigliucci M (1993): Control of phenotypic plasticity via regulatory genes. - American Naturalist, 142: 366-370.

[62] Simberloff D (2000): Introduced species: the threat to biodiversity and what can be done. -http://www.actionbioscience.org/biodiversity/simberloff.html.

[63] Stearns S (1992): The evolution of life histories. - Oxford University Press, UK.

[64] Sutherland S (2004): What makes a weed a weed: life history traits of native and exotic plants in the USA. - Oecologia, 141: 24-39.

[65] Szaniawski RK (1987): Plant stress and homeostasis: a hypothesis. - Plant Physiology and Biochemistry, 25:63-72.

[66] Thornley JM (1972): A balanced quantitative model for root:shoot ratios in vegetative plants. - Annals of Botany, 36: 431-441.

[67] Van de Vijver CADM Boot RGA Poorter H and Lambers H (1993): Phenotypic plasticity in response to nitrate supply of an inherently fast-growing species from a fertile habitat and an inherently slow- growing species from an infertile habitat. - Oecologia, 96: $548-554$.

[68] Venable DL Bừrquez A Corral G Morales E. and Espinosa F (1987): The ecology of seed heteromorphism in Heterosperma pinnatum in central Mexico. - Ecology, 68: 65-76.

[69] Watkinson A (1981): The population ecology of winter annuals. In: Synge H. (ed.) The Biological aspects of Rare Plant Conservation. - John Wiley and Sons, Chichester, UK.

[70] Watkinson AR and Harper JL (1978): The demography of the sand dune annual: Vulpia fasciculata. I. The natural regulation of population. - Journal of Ecology, 66: 15-33.

[71] Wilson JB (1988): A review of evidence on the control of shoot:root ratio in relation to models. - Ann. Bot. 61: 433-449 